\title{
COVID-19: Where Do We Go from Here? An Experience from Medical Students in India
}

\author{
Tanisha Kalra, ${ }^{1}$ Nikhita Kalra. ${ }^{2}$
}

\section{The Experience}

As animals saunter down the roads erstwhile earmarked for humans, we begin to think of the enormous thrust of this pandemic on our lives and yours...

Lockdown. Curfews. Containment zones. Hotspot regions sealed. All these are words that have become a part of our life now. Four weeks ago, who would've imagined that life would take such a drastic turn, whether good or bad is a highly individual perspective!

As we step into these uncertain times, we have become cognizant of "service before self" in the true sense. We wear our ammunition, our personal protective equipment (PPE) and go into the dark to combat an enemy that we have very little knowledge about. But the hurdle is the lack of ammunition, the scarcity of PPEs, forcing doctors to rummage through their inventories in this dire time. Who could've anticipated the dearth of masks, including the N95! It was this interlude offered by the lockdown which inspired us to ponder and read-up and we were shocked by the paucity of studies on nitty-gritty like N95 mask reuse vs extended single use. It was only a recent assessment that supported prioritising $\mathrm{N} 95$ extended use over reuse.

The gloom that preceded COVID-19 cases forced government organizations to sweat and slave, but enough attention was not paid to the importance of PPE. And now, the after-effects are evident, as an inadequately protected healthcare worker, is unknowingly spreading the virus. For instance, in Delhi when a patient with a travel history to an affected area went to see a doctor in a government run clinic and turned out to be positive for COVID-19 because of which the doctor and around 800 patients he had come in contact with had to be home quarantined for 14 days. ${ }^{2}$

This disease has all eyes glued to the news as we learn something new every day, protocols change by the hour. In light of new evidence, the CDC now recommends that everybody should wear at least a cloth mask when outside. 3 Several states in India have made wearing a mask mandatory and anybody not wearing a mask in public could face legal action.

Something which we can proudly say for our government is that it has excelled in its hour of trial. Its dedication to keep its citizens safe, implementing new strategies every day to flatten the curve and making it a point to ensure that people stay at home even if means taking legal action, is admirable. For most of us, this period of complete lockdown is unprecedented, something which we'll recount to our future generations.

But what bothers us a lot is the violence and atrocities that we as a medical community have to face in these times. Doctors and the paramedical staff are toiling away in hospitals, caring for patients despite a looming threat that they may also get infected with SARS CoV-2 along with the apprehension of infecting their families. Despite all this, there are several reports across India of landlords evicting healthcare workers, residents not being able to enter their houses and incidences of violence against doctors and nurses all because people believe that they might get infected if somebody caring for COVID-19 positive patients stays in the same locality as them..$^{4,5}$ It's hard to digest such information because the same people were applauding and cheering for the frontline works from their balconies a few days ago. ${ }^{6}$

As medical students living in this pandemic amidst lockdown, the future sometimes seems bleak. Several national level exams for entering into a residency which were scheduled for this period have been indefinitely postponed. In such scenarios, when your preparation is complete and you are almost ready for the exam, for the exam to be deferred brings in a lot of anxiety. It becomes difficult to study with no end in sight and to keep studying the same topics repeatedly.

Most academic institutes have taken the onus on their shoulders to maintain a continuity in the curriculum by organizing online classes. Though theoretical lectures continue, clinical rotations in medical schools remain suspended with no light at the end of the tunnel due to conversion of hospitals to exclusive COVID-19 centers. Unpredictability in such times has led to fears about this year being wasted and not being able to follow the set timelines. The only silver lining is that everyone around the world is in the same boat.

Everything isn't gloomy though! The lockdown has brought in a muchneeded break from the rigorous routine of medical school and its deadlines. The pandemic has ushered in loads of free time for recreational things. We can proudly say that we have impressed our mother by picking up the pieces of our co-curricular activities where they were left off before foraying into medical school! Most of all, there has been a lot of family time which the entire world had run out of sharing anecdotes over the dinner table or pulling one another's leg makes time go by in a jiffy. These were the trivial aspects of life that had been lost in our daily hectic routine. Joyce Meyer very rightly put it into words, 'Patience is not simply the ability to wait, it's how we behave while we're waiting'.

The Earth, burdened by the enterprising humans, is recovering in all forms- pollution, wildlife, climate... As another peacock rambled down our street, we realized how nefarious the mankind has been in some ways.

We don't know what the future holds but aren't we all contriving with earnest sincerity of what we shall do when this phase ends! And definitely hoping to come out as stronger and better individuals. But for now, let's all hang in and have faith!

\footnotetext{
MBBS, Maulana Azad Medical College, New Delhi, India

2 Medical student, Maulana Azad Medical College, New Delhi, India
}

About the Author: Tanisha Kalra graduated from Maulana Azad Medical College, New Delhi, India, in 2019. Nikhita Kalra is currently a 3 rd year medical student from Maulana Azad Medical College.

Address: 2, Bahadur Shah Zafar Marg, Maulana Azad Medical College Campus, Balmiki Basti, New Delhi, Delhi 110002, India 


\section{Experience}

\section{References}

1. Emergency Care Research Institute (ECRI). Clinical Evidence Assessment. Safety of Extended Use and Reuse of N95 Respirators. USA. Last updated March 23, 2020; cited April 9, 2020. Available from: https://www.elsevier.com/_data/assets/pdf_file/0006/997863/COVID-ECRI-N95Respirators_2020-03.pdf.

2. BBC. Coronavirus: More than 800 Indians quarantined as doctor tests positive. Last updated March 26, 2020, Cited April 9, 2020. Available from: https://www.bbc.com/news/world-asia-india-52048194.

3. Centers for Disease Control and Prevention (CDC). Use of Cloth Face Coverings to Help Slow the Spread of COVID-19. USA. Last updated April 9, 2020; cited April 9, 2020. Available from: https://www.cdc.gov/coronavirus/2019-ncov/preventgetting-sick/diy-cloth-face-coverings.html.
4. Pandey V. BBC. Coronavirus: India doctors 'spat at and attacked'. 2020. Last updated April 3, 2020; cited April 9, 2020. Available from: https://www.bbc.com/news/world-asia-india-52151141.

5. Kapoor C. COVID-19: India's frontline heroes decry harassment. Professionals leading India's battle against coronavirus face discrimination, distrust, and violence. Anadolu Agency. India; 2020. Last updated April 3, 2020; cited April 9, 2020. Available from: https://www.aa.com.tr/en/asia-pacific/covid-19-indiasfrontline-heroes-decry-harassment/1791396.

6. Tiwari V. NDTV. Watch: Clapping, Beating Utensils - How India Thanked COVID-19 Fighters. India; 2020. Last updated March 22, 2020; cited April 9, 2020. Available from: https://www.ndtv.com/india-news/coronavirus-clapping-beating-utensilsindias-thank-you-note-to-covid-19-fighters-2198843.

\section{Acknowledgments}

None.

Conflict of Interest Statement at Funding

The Authors have no funding, financial relationships or conflicts of interest to disclose.

Author Contributions

Conceptualization, Writing - Original Draft, Writing - Review at Editing: TK, NK.

Cite as:

Kalra T, Kalra N. COVID-19: Where Do We Go from Here? An Experience from Medical Students in India. Int J Med Students. 2020 Jan-Apr;8(1):66-67.

This work is licensed under a Creative Commons Attribution 4.0 International License

ISSN 2076-6327

This journal is published by the University Library System, University of Pittsburgh as part of the Digital Publishing Program and is co-sponsored by the University of Pittsburgh Press. 